\title{
Procrastination and laziness rates among students with different academic performance as an organizational problem
}

\author{
Denis Dautov ${ }^{1, *}$ \\ ${ }^{1}$ Don State Technical University, Rostov-on-Don, Russia
}

\begin{abstract}
Displays and causes of laziness and procrastination vary in both their essence and the influence they have on human activity. Students with different academic performance tend to display laziness and procrastination in different ways. The results of the research on procrastination and laziness patterns, shown by students with various academic performance rates, are described in the article. The levels and causes of laziness and procrastination for students with different academic performance were defined by means of diagnostic methodology. Based on the methods of Mathematical Statistics, such as the Spearman's rank correlation coefficient and the Mann-Whitney $U$ test, the levels of procrastination and laziness were compared in correspondence with students' academic performance rates. A negative correlation was discovered between the level of academic procrastination and students' academic performance. Another correlation was established for such causes of laziness as "Capability deficiency" and "Lack of interest". The differences in laziness levels as well as causes of laziness and procrastination were identified between students with high and low academic performance rates. A conclusion was made that in the process of forming the basic conditions for studying, it is highly important to recognize displays of procrastination and laziness among students with different academic performance rates.
\end{abstract}

\section{Introduction}

Constant and rapid changes in living conditions, as well as professional and academic activities, the increasing demands for self-management and self-control in human society, as well as the general increase in the level of anxiety and even fear of new information have become the characteristic traits of modern society [1]. Due to this fact, such phenomena as procrastination and laziness have become the object of the growing interest. However, there is still a significant lack of researches on this problem in modern Psychology.

The level of procrastination and laziness defines the whole range of organizational behavior patterns, which occur in the process of solving professional and academic tasks. It also specifies the peculiarities of perceiving working situations, the vulnerability to distress

\footnotetext{
* Corresponding author: dautov-80@mail.ru
} 
and its effects as well as the general perception of activity and surroundings in which it is performed.

Despite the fact that many researchers have confirmed a strong dependence on the level of laziness and procrastination, the terminology areas of procrastination and especially laziness still reflect significant notional contradictions. New features constantly get added to these notions. Procrastination is often mixed with laziness, and their peculiar characteristics get combined within one conceptual field [2-4].

According to surveys, $70-95 \%$ of people in Eurasia and North America admit feeling a desire to postpone completion of scheduled tasks, and almost $25 \%$ of them see this tendency as chronic [6]. It should be mentioned that students, who cannot overcome academic procrastination, experience more organizational and psychological problems than working people [7]. About $70-75 \%$ of students tend to postpone the beginning of performing some academic activities, such as completing supplementary tasks, writing course papers and preparing for seminars. Despite such tendencies, Psychology of Organization has developed more advanced procrastination and laziness control technologies than Psychology of Education. Most psychological researches on the learning process neglect the necessity to correlate the phenomena of procrastination and laziness among students. With minor exceptions, they are viewed as independent and not related to each other [8]. At the same time, the widespread apathy of students during the learning process has become one of the major problems of education.

A number of studies show the negative effect of academic procrastination on students' physical well-being as it leads to psychosomatic diseases, sleeping and eating disorders, and grave emotional problems, such as affective states, chronic anxiety, guilt, and depression. The majority of students admit being afraid to fail when they have to complete tasks, which results in limiting the goals they set and achieve. Such intention often leads to the loss of productivity and decrease in general efficiency. It should be noted that such state has a significant destructive impact on students' social interaction within the academic environment, and undermines relations with teachers and people outside the educational establishment $[9,10]$.

Moreover, some researches state that academic procrastination and laziness affect students' academic achievements in the process of learning. According to researches by P. Steel, in most cases procrastination causes a steady decline in academic performance [6]. B. Bukhori emphasizes the fact that procrastination instigates students to achieve academic goals by fraud, as they plagiarize when writing papers and cheat on exams [11].

However, the influence of procrastination is not considered to be purely negative. G. Schraw et al. emphasize that fear of failure can not only limit students' ambitions, but can also stimulate a more diligent activity, which can improve the quality of education [12]. Moreover, the authors discovered that some students enjoyed working under strict time limiting conditions, especially when approaching the deadline. In this case, students tend to be proud of their ability to work efficiently under time pressure, when the quality of learning activity gets higher despite time limits. Consequently, procrastination does not necessarily have destructive impact on productivity and quality of students' learning activity [12].

Nevertheless, it should be mentioned that in such cases the reason may lie in the lack of distinction between procrastination and laziness. If the work is organized in such a way that a person cannot postpone completing a task, it deals more with limitation or self-limitation, which makes people act, thus weakening their inner resistance. In this case, the phenomenon observed is not procrastination, but laziness.

To understand the real correlation between these phenomena in human behaviour, it is necessary to define the application ranges for both notions. 
Originally, the phenomena of procrastination and laziness were viewed as inseparable. Both laziness and procrastination used to be defined as a mental state of not wanting to do something, whenever any significant effort of will is required $[8,9,12,13]$.

A. Binet was one of the first researchers, who attempted to distinct these notions. He believed laziness to be a certain inborn human trait, while procrastination was seen as a form of situational behavior, which appeared under definite circumstances. As he developed a cognitive abilities test, the author got concerned whether the terms "laziness" and "lack of will" were used correctly when interpreting the results of task solving. According to A. Binet, procrastination can be explained by a temporary loss of motivation, after regaining of which a person resumes active work. Laziness, however, is considered to be a much rarer phenomenon, which can be explained by such trait as "inertia" [14].

The first researches on procrastination proper were conducted by foreign psychologists S. Lay, N. Milgram, P. Steel, W. Simpson and J. Ferrari.

S. Lay introduced a significantly wider notion by defining procrastination as a voluntary irrational intention to postpone planned actions without realizing the negative consequences the procrastinator will have to face [15]. Later on, the definition underwent numerous amendments and changes. For example, N. Milgram's research distinguished several types of procrastination (academic, daily, compulsive and neurotic). R. Tenne then divided all the types into two main categories: putting off task solving, and putting off decision making [16]. P. Steel sees procrastination as a specific strategy of avoiding work, which triggers negative emotions [6]. W. Simpson and J. Ferrari have a different understanding of the phenomenon and believe that people try to force themselves to solve tasks as quickly as possible by means of evoking intense emotions [17,18].

Russian psychologists A. Gorbunova, S. Mokhova, A. Nevzorov and partly Y. Varvaricheva [19] tend to view the phenomenon of procrastination as a set of personality traits, thereby making it similar to laziness. V. Vorobyova, E. Ilyin and S. Posokhova consider that, despite objective differences between laziness and procrastination, both phenomena are based on similar or even identical mechanisms, which directly depend on low motivation and will [20].

Few foreign researches have been devoted to the problem of laziness. In one of them, L. Tomasevic and Z. Kresimir prove the purely social character of the phenomenon. They believe that, as the definition of laziness depends on social and cultural context, it can be described as a specific form of an individual's social interaction, or, to be more precise, the lack of such interaction [21].

Furthermore, despite the significant contradictions in the understanding of procrastination and laziness, researchers notice a tendency for a strong correlation between these phenomena $[9,12,13]$. Moreover, the causes of academic procrastination and laziness during studying seem to be almost identical.

Among numerous causes, researchers single out the difficulty of the task as the major factor of academic procrastination and laziness [22]. The difficulty can be understood as the clarity of the problem, its volume (defined by the time input) as well as the information and knowledge, required to solve it. If the task is too difficult, students will have trouble trying to apply their skills and will most likely refuse to make efforts at all, as solving the task will seem to be a waste of energy. On the contrary, a task that is too easy reduces motivation and results in the loss of interest [17].

Another cause, which triggers laziness and academic procrastination, is the importance of the task. As the deadline comes due, it gets harder for a student to refuse to work, hence many students get down to solving tasks just before the deadline [23].

As can be seen, general causes of academic procrastination and laziness have organizational nature. Students' consistency in education can be achieved by changing the way in which training materials are delivered, such as dividing large tasks into smaller, but 
interconnected components. Moreover, it can decrease mental workload and facilitate higher quality of task solving [22].

However, without distinction between specific characteristics of academic procrastination and laziness, introducing organizational changes alone to the educational process will not be sufficient. The research outcomes allow us to conclude that the main difference between these phenomena lies in the starting point of their appearance. Laziness makes students postpone the decision on starting to work, while procrastination leads to putting off the work itself, as the decision on its necessity has already been made. Thus, the nature of laziness is strategic, as it determines whether there is an intention to perform the activity. In contrast, procrastination can be considered tactical, as it defines the beginning of such action, but not the necessity of performing it. Consequently, to introduce efficient organizational changes to the educational process, it is vital to define what exactly hinders students from learning - academic procrastination or laziness. Furthermore, it should be taken into account that displays of such phenomena may differ for students with high and low academic performance rates.

\section{The research methods and procedure}

The research engaged 40 males and females from 17 to 18 years old. Participants were divided into two groups according to their academic performance level. The first group consisted of high performing students (with the average grade above 4,2). The second group included low performing students (with the average grade below 3,7). The test audience consisted of first-year Liberal Arts students of Don State Technical University.

The following methods were used to analyze laziness and procrastination during the research:

1. The "Self-assessment of laziness" method (D. Bogdanova, S. Posokhova) was used to study the level of laziness [24].

2. The "Procrastination scale for students" method (S. Lay) was used to study the level of procrastination [25].

3. The "Diagnosis of prerequisites and attitudes to laziness" method (D. Bogdanova, S. Posokhova) was used to study the causes of laziness [26].

4. The "Questionnaire on propensity for procrastination" method (O. Shirvari, E. Chernaya, V. Panov) was used to study the causes of procrastination [27].

The use of two methods for the diagnosis of each phenomenon was determined by the necessity to evaluate other factors besides quantity and quality.

The Spearman's rank correlation coefficient and the Mann-Whitney U test were used as the methods of statistical analysis. The analysis was carried out via the SPSS Statistics software, version 17 .

\section{Results}

In order to obtain the results, shown in Table 2, the Spearman's rank correlation coefficient test was used to find the relationship between academic performance and indices of laziness and procrastination. 
Table 1. Correlation of laziness and procrastination rates for students with high and low academic performance.

\begin{tabular}{|c|c|c|c|c|c|c|c|c|c|c|c|c|c|}
\hline \multirow{3}{*}{$\begin{array}{l}\text { Aca- } \\
\text { demi } \\
\text { c } \\
\text { per- } \\
\text { form } \\
\text { ance } \\
\text { rate }\end{array}$} & \multirow{2}{*}{\multicolumn{2}{|c|}{$\begin{array}{l}\text { Self- } \\
\text { assessment } \\
\text { of laziness }\end{array}$}} & \multirow{2}{*}{\multicolumn{2}{|c|}{$\begin{array}{l}\text { Academic } \\
\text { procrastinat } \\
\text { ion }\end{array}$}} & \multicolumn{6}{|c|}{ Causes of laziness } & \multicolumn{3}{|c|}{$\begin{array}{ll}\text { Causes } & \text { of } \\
\text { procrastination }\end{array}$} \\
\hline & & & & & \multicolumn{2}{|c|}{$\begin{array}{l}\text { Peculiar } \\
\text { state }\end{array}$} & \multicolumn{2}{|c|}{$\begin{array}{l}\text { Capability } \\
\text { deficiency }\end{array}$} & \multicolumn{2}{|c|}{$\underset{\text { interest }}{\text { Lack of }}$} & \multicolumn{2}{|c|}{$\begin{array}{l}\text { Personal } \\
\text { procrastinat } \\
\text { ion }\end{array}$} & \multirow{2}{*}{$\begin{array}{l}\begin{array}{l}\text { Situat } \\
\text { ional } \\
\text { procr } \\
\text { astina } \\
\text { tion }\end{array} \\
\begin{array}{l}\text { Pears } \\
\text { on's } \\
\text { R }\end{array}\end{array}$} \\
\hline & $\begin{array}{l}\text { Pears } \\
\text { on's } \\
\text { R }\end{array}$ & $\begin{array}{l}\text { Aver } \\
\text { age }\end{array}$ & $\begin{array}{l}\text { Pears } \\
\text { on's } \\
\text { R }\end{array}$ & $\begin{array}{l}\text { Aver } \\
\text { age }\end{array}$ & $\begin{array}{l}\text { Pears } \\
\text { on's } \\
\text { R }\end{array}$ & $\begin{array}{l}\text { Aver } \\
\text { age }\end{array}$ & $\begin{array}{l}\text { Pears } \\
\text { on's } \\
\text { R }\end{array}$ & $\begin{array}{l}\text { Aver } \\
\text { age }\end{array}$ & $\begin{array}{l}\text { Pears } \\
\text { on's } \\
\text { R }\end{array}$ & $\begin{array}{l}\text { Aver } \\
\text { age }\end{array}$ & $\begin{array}{l}\text { Pears } \\
\text { on's } \\
\mathbf{R}\end{array}$ & $\begin{array}{l}\text { Aver } \\
\text { age }\end{array}$ & \\
\hline $\begin{array}{l}\text { High } \\
\text { rate }\end{array}$ & $-\overline{0}-621$ & 3.15 & $-\overline{0}$ & 54.5 & 0.175 & 3.55 & 0.485 & 5.88 & - & 4.5 & 0.261 & 4.65 & -0.564 \\
\hline $\begin{array}{l}\text { Low } \\
\text { rate }\end{array}$ & -0.21 & 4.55 & $-\overline{0}-855$ & 63.9 & 0.147 & 4.05 & - & 3.7 & $-\overline{0}$ & 4.77 & - & 6.95 & -0.334 \\
\hline
\end{tabular}

A negative correlation $(r=-0,621 ; p<0,01)$ was established between high academic performance and the laziness self-assessment rate. Hence, according to students within the high-performance group, the higher their performance rate is, the lower laziness level they demonstrate. No correlation with the self-assessment of laziness rate was found for low performing students $(\mathrm{r}=-0,21 ; \mathrm{p}<0,01)$. The average of laziness self-assessment appears to be significantly higher for students with low academic performance $(4,55)$ than the highperformance group $(3,15)$.

A negative correlation with the academic procrastination rate was found for students with both high and low academic performance. Low performing students show a more significant correlation with academic procrastination $(\mathrm{r}=-0,855 ; \mathrm{p}<0,01)$ than high performing students $(r=-0,494 ; p<0,01)$. Within the low-performance group there is a stronger tendency, showing that a decreasing level of academic performance is accompanied by an increasing level of academic procrastination. The average of procrastination is higher among students with low academic performance $(63,9)$ than among high performing students $(54,5)$.

The correlation of students' high and low academic performance rates with such cause of laziness as "Peculiar state" appears insignificant with $r=0,175 ; \mathrm{p}<0,01$ and $r=0,147$; $<0,01$ respectively. The average of the "Peculiar state" cause is found higher for students with low academic performance $(4,05)$ than for high performing students $(3,55)$. Regardless of the academic performance rate, students believe that their reluctance to perform a certain activity is not related to a state of discomfort, when people get lazy because they feel tired or unwell. However, the high average proves that students with low academic performance show a stronger propensity for laziness and attribute it to feeling tired or ill more often.

A positive correlation $(\mathrm{r}=0,485 ; \mathrm{p}<0,01)$ was established between the high academic performance rate and such cause of laziness as "Capability deficiency", while no significant correlation was discovered for students with low academic performance $(r=-0,345 ; \mathrm{p}<$ $0,01)$. Hence, within the high-performance group, the higher the performance rate is, the more students tend to explain their laziness by inability to obtain the required information and start working due to the insufficient competence or the objective lack of time. The "Capability deficiency" average appears to be much higher for students with high academic performance $(5,88)$ than for the low-performance group $(3,7)$. Low performing students do not consider lack of capabilities to be a major cause of laziness.

Among students with low academic performance there is a strong negative correlation ( $\mathrm{r}$ $=-0,902 ; \mathrm{p}<0,01)$ with such cause of laziness as "Lack of interest", while no significant 
correlation was established for high performing students $(r=-0,159 ; \mathrm{p}<0,01)$. Hence, within the low-performance group, the lower performance rates get, the more inclined students are to get lazy due to the lack of interest in studying or cognitive activity. The "Lack of interest" average is also somewhat higher for low performing $(4,77)$ than high performing $(4,5)$ students.

The correlation between students' high and low academic performance rates with such cause of procrastination as "Personal procrastination" is considered insignificant with $\mathrm{r}=$ 0,$261 ; \mathrm{p}<0,01$ and $\mathrm{r}=-0,145 ; \mathrm{p}<0,01$ respectively. The average of "Personal procrastination" is higher for students with low academic performance $(6,95)$ than high performing students $(4,65)$. Thus, the increase or decrease in the academic performance rate does not influence students' idea, that their desire to postpone completing a certain task may be caused by their peculiar personality traits. Still, students with different academic performance rates admit having such personality traits, which trigger academic procrastination.

A negative correlation $(\mathrm{r}=-0.564 ; \mathrm{p}<0,01)$ was discovered between high academic performance and such cause of procrastination as "Situational procrastination". At the same time, there is no significant correlation for low-performing students $(r=-0,334 ; p<0,01)$. Consequently, within the high-performance group, the higher students' academic performance is, the less they tend to put off their tasks due to the lack of extrinsic motivation or favourable conditions. The average of "Situational procrastination" is higher for high performing $(5,4)$ than low performing $(4,55)$ students.

In order to obtain the results, shown in Table 2, the Mann-Whitney $U$ test was used to find the differences in laziness and procrastination rates for students with high and low academic performance.

Table 2. The differences in laziness and procrastination rates for students with high and low academic performance.

\begin{tabular}{|c|c|c|c|c|c|c|c|c|c|c|c|c|c|}
\hline \multirow{3}{*}{$\begin{array}{l}\text { Aca } \\
\text { de- } \\
\text { mic } \\
\text { per- } \\
\text { for- } \\
\text { ma } \\
\text { nce } \\
\text { rate }\end{array}$} & \multirow{2}{*}{\multicolumn{2}{|c|}{$\begin{array}{l}\text { Self- } \\
\text { assessment } \\
\text { of laziness }\end{array}$}} & \multirow{2}{*}{\multicolumn{2}{|c|}{$\begin{array}{l}\text { Academic } \\
\text { procrastinati } \\
\text { on }\end{array}$}} & \multicolumn{6}{|c|}{ Causes of laziness } & \multicolumn{3}{|c|}{$\begin{array}{l}\text { Causes of } \\
\text { procrastination }\end{array}$} \\
\hline & & & & & \multicolumn{2}{|c|}{$\begin{array}{l}\text { Peculiar } \\
\text { state }\end{array}$} & \multicolumn{2}{|c|}{$\begin{array}{l}\text { Capability } \\
\text { deficiency }\end{array}$} & \multicolumn{2}{|c|}{$\begin{array}{l}\text { Lack of } \\
\text { interest }\end{array}$} & \multicolumn{2}{|c|}{$\begin{array}{l}\text { Personal } \\
\text { procrastinati } \\
\text { on }\end{array}$} & $\begin{array}{l}\text { Situati } \\
\text { onal } \\
\text { procra } \\
\text { stinati }\end{array}$ \\
\hline & $\begin{array}{l}\text { Av } \\
\text { er- } \\
\text { age }\end{array}$ & $\begin{array}{l}\text { Man } \\
\text { n- } \\
\text { Whit } \\
\text { ney } \\
\text { U }\end{array}$ & $\begin{array}{l}\text { Aver } \\
\text { age }\end{array}$ & $\begin{array}{l}\text { Man } \\
\text { n- } \\
\text { Whit } \\
\text { ney } \\
\text { U }\end{array}$ & $\begin{array}{l}\text { Aver } \\
\text { age }\end{array}$ & $\begin{array}{l}\text { Man } \\
\text { n- } \\
\text { Whit } \\
\text { ney } \\
\text { U }\end{array}$ & $\begin{array}{l}\text { Aver } \\
\text { age }\end{array}$ & $\begin{array}{l}\text { Man } \\
\text { n- } \\
\text { Whit } \\
\text { ney } \\
\text { U }\end{array}$ & $\begin{array}{l}\text { Aver } \\
\text { age }\end{array}$ & $\begin{array}{l}\text { Man } \\
\text { n- } \\
\text { Whit } \\
\text { ney } \\
\text { U }\end{array}$ & $\begin{array}{l}\text { Aver } \\
\text { age }\end{array}$ & $\begin{array}{l}\text { Man } \\
\text { n- } \\
\text { Whit } \\
\text { ney } \\
\text { U }\end{array}$ & $\begin{array}{l}\text { Avera } \\
\text { ge }\end{array}$ \\
\hline $\begin{array}{l}\text { Hig } \\
\mathrm{h} \\
\text { rate }\end{array}$ & $\begin{array}{l}3.1 \\
5\end{array}$ & \multirow{2}{*}{93.5} & 54.5 & \multirow{2}{*}{137} & 3.55 & \multirow{2}{*}{144.5} & 5.88 & \multirow{2}{*}{52.5} & 4.5 & \multirow{2}{*}{186} & 4.65 & \multirow{2}{*}{102} & 5.4 \\
\hline $\begin{array}{l}\text { Lo } \\
\mathrm{W} \\
\text { rate }\end{array}$ & $\begin{array}{l}4.5 \\
5\end{array}$ & & 63.9 & & 4.05 & & 3.7 & & 4.77 & & 6.95 & & 4.55 \\
\hline
\end{tabular}

The comparison between students with high and low academic performance revealed statistically valid differences in the self-assessment of laziness rates $\left(U_{e m p}=93,5\right.$ at $p<$ 0,01). Among low performing students the rates of the self-assessed laziness are significantly higher than among their advanced fellow students. Those with lower academic 
performance aim less at achieving positive results and allow themselves to get lazy, which prevents them from starting work.

On the contrary, high performing students consider learning and working activities more important than rest and leisure and have a greater propensity for staying determined and active when completing tasks.

The results of academic procrastination rates comparison between students with high and low academic performance appear to be within the area of uncertainty $\left(\mathrm{U}_{\mathrm{emp}}=137\right.$ at $\mathrm{p}<0,01)$. Procrastination rates vary from student to student, and it is impossible to divide high- and low-performance groups according to their propensity for putting off learning activities. In general, students admit the tendency to delay the necessary activities or postpone making decisions on performing them.

The comparison between students with high and low academic performance did not reveal any statistically valid differences in such cause of laziness as "Peculiar state" $\left(\mathrm{U}_{\mathrm{emp}}\right.$ $=144,5$ at $\mathrm{p}<0,01)$. Neither high nor low performing students tend to attribute reluctance to work to their current state of being tired or unwell.

The differences in "Capability deficiency" cause appear to be statistically significant between students with high and low academic performance rates $\left(U_{e m p}=144,5\right.$ at $p<$ 0,01). Advanced students show a stronger tendency to get lazy due to the lack of facilities, equipment or tools, necessary for task solving. Their reluctance to work is attributed to unmanageable objective obstacles.

The comparison of the "Lack of interest" cause rates between high and low performing students did not reveal any statistically valid differences $\left(U_{e m p}=186\right.$ at $\left.p<0,01\right)$. Regardless of their academic performance, students tend to refuse to accomplish certain purposes and tasks in case the process or result does not activate cognition or seem interesting.

Statistically significant differences were discovered $\left(U_{\text {emp }}=102\right.$ at $\left.p<0,01\right)$, when the "Personal procrastination" cause rates were compared for the students of both groups. Students with lower academic performance believe that the desire to postpone certain tasks is caused by their peculiar personality traits. High performing students, however, rarely consider personality traits to be a major cause of their procrastination.

The comparison of the "Situational procrastination" cause rates between high and low performing students did not reveal any statistically valid differences $\left(U_{e m p}=145\right.$ at $p<$ $0,01)$. Regardless of their academic performance rates, students tend to postpone work in response to the decrease in extrinsic motivation. A certain reward is required to encourage them to perform tasks.

\section{Discussion and conclusions}

The presented results prove that in general, students with low academic performance are more subject to laziness and procrastination. Capability deficiency can be defined as the main cause of laziness for high performing students, while the group with low academic performance attributes laziness to the lack of interest. For the high-performance group, the major cause of procrastination is the specific conditions of activity, but for low performing students it is the personality traits, which hinder them from starting work. However, the fact is that sometimes it is not the absolute high or low academic performance that matters, but the relative performance rate within the high and low performing groups [14]. Besides, a number of cases prove that laziness, procrastination or their causes are typical of both high and low performing students, hence the increasing level of laziness or procrastination does not necessarily depend on the decreasing academic performance rate. In other words, 
academic performance has not only quantitative, but also qualitative characteristics [8]. The advanced students' attitude to studying appears to be essentially different from that of low performing students, although the quantitative differences in their grades may be insignificant.

The results of the research allow us to make the following conclusions:

1. Self-assessment of laziness is significantly higher among students with low academic performance. At the same time, within the high-performance group, the higher the average grade is, the lower the level of self-assessed laziness appears to be. No such correlation was established within the low-performance group. Consequently, students with low academic performance show variable, but generally high propensity for laziness, which prevents them from improving their grades. However, upon reaching a certain level of academic performance, the less students consent to laziness, the better grades they get.

2. The level of academic procrastination is considered to be higher for low performing students compared to their high performing peers. In both groups, the higher the grades, the lower the academic procrastination rates are. However, this tendency is more prominent among the low-performance group. Thus, academic procrastination has the strongest impact on students, who achieve relatively low academic results. As the performance rate gets higher, fighting procrastination no longer facilitates the improving of academic achievements. It may occur due to the fact that there is a definite level of procrastination, which allows a student to postpone the activity, but then resume it successfully before the deadline.

3. The main cause of laziness for the high-performance group is found to be the lack of certain capabilities, knowledge or tools. According to the research results within this group, students with higher grades tend to show a stronger propensity for refusing to work due to this cause. The improving of the performance rate within the group seems to appear because of the students' increasing resistance to major causes of laziness, which implies will and discipline. However, students still remain subject to putting off activities, which require complex labour-consuming preparation. Low performing students name the lack of interest to the content or activity itself as the main cause of laziness. The tendency for the low-performance group is that the lower the performance rate gets, the more students refer to this cause. Hence, the level of academic performance within this group depends on the primary interest of students in the learning content or teaching methods. Taking into account that the only significant differences between the groups were found in the "Capability deficiency" cause rate, a conclusion can be made that high performing students have already overcome the influence of personal interest on their productivity and can now control it during studying. At the same time, low performing students have not yet reached the level, on which reluctance to work is caused by objective obstacles.

4. The main cause of procrastination for high performing students is the lack of favourable conditions to start working. Within this group, the lower performance rate is, the more students tend to procrastinate due to this cause. For low performing students, however, "Personality traits" becomes the major cause of procrastination. Taking into account that the only significant differences between the groups were found in the "Personality traits" cause rate, a conclusion can be made that low academic performance is generally defined by peculiar personality traits, which do not let students overcome unfavourable conditions at the beginning of work. However, upon reaching a certain level of academic performance, it gets easier for students to deal with such conditions, which make them postpone planned actions, and they do not longer tend to attribute difficulties to their personality traits.

To conclude the research, it can be stated that the problem of difficulties in learning can be solved by means of identifying the levels and causes of laziness and procrastination for students with different academic performance rates. The differentiated approach should be 
applied when forming the basic conditions of setting tasks and providing the necessary tools for solving them.

\section{References}

1. V.I. Pishchik, Social psychology and society 10(2), 67-81 (2019) doi:10.17759/sps.2019100206

2. D.M.S. Corkin, S.F. Lindt, P.S. Williams, Learning Environments Research, 1-15 (2020)

3. D.M.S. Corkin, S. Yu, S.F. Lindt, Learning and Individual Differences 21(5), 602-606 (2011)

4. P. Steel, Personality and Individual Differences 48(8), 926-934 (2010)

5. K. Krause, A.M. Freund, Personality and Individual Differences 63, 75-80 (2014)

6. P. Steel, K.B. Klingsieck, Australian Psychologist 51(1), 36-46 (2016)

7. B.E. Çapan, Procedia-Social and Behavioral Sciences 5, 1665-1671 (2010)

8. E.Yu. Panchuk, A.Yu. Preina, Modern technologies and scientific and technological progress 1(7), 326-327 (2020) doi:10.36629/2686-9896-2020-1-326-327

9. C. Grunschel, S. Fries, European Journal of Psychology of Education 28(3), 841-861 (2013)

10. J. Patrzek, C. Grunschel, S. Fries, International Journal for the Advancement of Counselling 34(3), 185-201 (2012)

11. B. Bukhori, Psympathic: Jurnal Ilmiah Psikologi 6(2), 201-212 (2019)

12. G. Schraw, T. Wadkins, L. Olafson, Journal of Educational psychology 99(1), 12 (2007).

13. J.N. Choi, S.V. Moran, The Journal of social psychology 149(2), 195-212 (2009)

14. J.H. Kranzler, R.G. Floyd, Assessing Intelligence in Children and Adolescents: A Practical Guide for Evidence-Based Assessment (Rowman \& Littlefield Publishers, Lanham, Maryland, 2020)

15. L.A. Rabin, J. Fogel, K.E. Nutter-Upham, Journal of clinical and experimental neuropsychology 33(3), 344-357 (2011)

16. M. Hen, M. Goroshit, Current Psychology 39(2), 556-563 (2020)

17. J.R. Ferrari, J.F. Díaz-Morales, Journal of Research in Personality 41(3), 707-714 (2007)

18. A. Simpson, W. Kyle, T.A. Pychyl, Personality and Individual Differences 47(8), 906911 (2009)

19. Y.I. Varvaricheva, Psychology http://elibrary.ru/item.asp?id=18931766

3, $\quad 121-130$

(2010)

20. A.A. Cevrimici, Vestnik of South Ural State University. Series «Psychology» 9(3), 104-113 (2016) doi: http://dx.doi.org/10.14529/psy160311

21. L. Tomašević, N. Gosić, R. Gale, Socijalna ekologija: časopis za ekološku misao i sociologijska istraživanja okoline 14, 1-2 (2005)

22. D.S. Ackerman, B.L. Gross, Journal of Marketing education 27(1), 5-13 (2005)

23. A.J. Howell, D.C. Watson, Personality and Individual Differences 43(1), 167-178 (2007). 
24. E.P. lyin, Work and personality. Workaholism, perfectionism, laziness (Peter, SaintPetersburg, 2016) https://books.google.ru/books?hl=ru\&lr=\& $\mathrm{id}=$ GHfWCwAAQBAJ\&oi=fnd\&pg=PA6\&dq

25. O.S. Windecker, M.V. Ostanina, Actual problems of psychological knowledge 1(30), 116-126 (2014) https://elibrary.ru/item.asp?id=21344075

26. S.T. Posokhova, Handbook of a practical psychologist. Psychodiagnostics (AST, Moscow, St. Petersburg, 2005) https://www.elibrary.ru/item.asp?id=21244246

27. O.A. Shirvari, Young scientist 24, 1105-1113 (2015) https://moluch.ru/archive/104/24362/ 